\title{
PELATIHAN DAN PENDAMPINGAN PENULISAN ARTIKEL HASIL PENELITIAN BAGI GURU-GURU DI KABUPATEN KLUNGKUNG DAN KARANGASEM
}

\author{
oleh, \\ I Made Kirna \\ Fakultas Matematika dan IPA \\ Universitas Pendidikan Ganesha
}

\begin{abstract}
ABSTRAK
Kegiatan pengabdian pada masyarakat ini bertujuan untuk (1) meningkatkan kemampuan guru-guru SMP dan SMA di Kabupaten Klungkung dan Karangasem menulis artikel hasil penelitiannya sesuai dengan gaya selingkung jurnal nasional terakreditasi, dan (2) membantu guru-guru di Kabupaten Klungkung dan Karangasem mempublikasikan artikel hasil penelitiannya jurnal ilmiah, khususnya Jurnal Pendidikan dan Pengajaran (JPP) Undiksha. Untuk mencapai tujuan tersebut dilakukan kegiatan pelatihan dan pendampingan yang dilakukan secara tatap muka dan online. Kegiatan pelatihan dan pendampingan ini dilaksanakan pada tanggal 30 Agustus 2013. Peserta yang terlibat dalam kegiatan ini adalah guru-guru SMAN di Kabupaten Klungkung dan Karangasem sebanyak 20 orang. Hasil kegiatan menunjukkan bahwa (1) peserta memiliki wawasan tentang jurnal dan cara penulisan artikel hasil penelitian sesuai dengan standar kualitas artikel; (2) empat peserta memiliki naskah yang siap diproses lebih lanjut di JPP Undiksha.
\end{abstract}

Kata-kata kunci: pelatihan, penulisan artikel ilmiah, pengabdian masyarakat

\begin{abstract}
This society services activities aimed at (1) improving teacher konwlege and skill in writing scientifict article based on their research result, and (2) helping teachers from Klungkung and Karangasem Regencies to publish their research in the journal, especialy Jurnal Pendidikan dan Pengajaran (JPP) Undiksha. Trainning and mentoring was held to achieve those goals via face to face and online activities. Face to face training and mentoring was held on $30^{\text {th }}$ of August 2013 and then continued to online mentoring. The 20 participants of senior high school (SMAN) teachers from Klungkung and Karangasem Regencies were included. The result revealed that (1) this activities can improve the knowledge and skills of the participants related to the journal and writing scientifict article, and (2) four draft of articles created by participants has good qualities which are ready to further mentored and proccessed in JPP Undiksha
\end{abstract}

Keywords: training, scientifict article writing, society services 


\section{Pendahuluan}

Guru sebagai jabatan fungsional dituntut tidak hanya kompeten dalam mengelola pembelajaran, tetapi juga didorong mampu mengembangkan kompetensi lain yang gayut dengan kompetensi pokok tersebut sebagai bagian dari professionalnya. Seiring dengan tuntutan profesional ini, mulai tahun 2009, Kementerian Negara Pendayagunaan Aparatur Negara dan Reformasi Birokrasi mengeluarkan Permen 16 Tahun 2009 yang mengatur tentang Jabatan Fungsional Guru dan Angka Kreditnya. Permen ini menuntut guru untuk mampu menghasilkan karya tulis ilmiah, seperti menulis artikel dalam jurnal ilmiah. Sekarang ini, kemampuan dalam publikasi ilmiah semakin dipandang penting dalam dunia pendidikan nasional. Hal ini dapat dilihat dari adanya persyaratan mempublikasi artikel sebagai syarat kelulusan S1, S2, dan S3, dan juga persyaratan kenaikan pangkat guru.

Kemampuan dan keterampilan dalam menulis artikel ilmiah tidak bisa dilepaskan dari kegiatan penelitian. Penggalakan penelitian tindakan kelas di kalangan guru telah mampu mendorong sebagian guru untuk melakukan penelitian. Demikian pula, kesadaran akan pengembangan diri telah mendorong guru studi lanjut ke jenjang S2. Dengan kata lain, beberapa guru telah melakukan penelitian, tetapi sebagian besar dari hasil penelitiannya tersebut hanya terhenti pada laporan penelitian. Hanya sedikit saja guru yang aktif menulis dan mempublikasikan hasil penelitiannya. Hal ini disebabkan oleh kemampuan menulis artikel ilmiah di kalangan guru masih rendah. Dengan demikian, peningkatan kemampuan dan keterampilan menulis artikel hasil penelitian menjadi kebutuhan guru yang mendesak.

Pada sisi yang lain, jurnal berkala ilmiah sebagai wadah dokumentasi dan penyebarluasan informasi ilmiah sangat membutuhkan sumbangan artikel. Sampai sekarang ini, pengelola jurnal kebanyakan mengalami kendala kurangnya sumbangan artikel yang kualitasnya memadai. Dilema pengelola jurnal selalu berkisar di antara mempertahankan kontinyuitas terbitan dan menjaga kualitas atikel yang diterbitkan. Sebagian besar pengelola jurnal, termasuk Jurnal Pendidikan dan pengajaran (JPP) yang dinaungi oleh Undiksha, mengalami kendala sumbangan artikel yang kualitasnya memadai. Pekerjaan dewan penyunting jurnal menjadi sangat berat untuk menyunting satu sumbagan artikel sampai menjadi memadai untuk diterbitkan. 
Dalam rangka mengembangkan status jurnal menjadi jurnal berkala ilmiah terakreditasi, jurnal menstandarkan kualitas artikel yang dimuatnya sesuai dengan kriteria jurnal nasional terkareditasi. Oleh sebab itu pengelola jurnal membutuhkan sumbangan artikel yang berkualitas. Selain dari aspek kualitas, salah satu tuntutan yang menjadi tantangan terberat pengelola jurnal nasional menuju terakreditasi adalah persentase penulis luar sebanyak minimal 60\% (Peraturan Dikti No 29 tahun 2011). Tantangan ini akan menjadi lebih mudah dipecahkan apabila sudah terbentuk budaya menulis artikel hasil penelitian di kalangan guru di propinsi Bali karena artikel hasil penelitian dari guru termasuk salah satu kategori artikel luar dilihat dari sudut pandang Undiksha. Dari paparan di atas sangat jelas dilihat bahwa kebutuhan guru dan kebutuhan pengelola jurnal sesungguhnya gayut satu sama lain, sehingga kerjasama keduanya perlu diigiatkan secara berkesinambungan.

Dalam rangka menjaring artikel dari guru-guru, JPP, slah satu jurnal yang dikelola oleh Undiksha, telah berupaya melakukan sosialisasi dan mengundang guru-guru untuk menyumbangkan artikel hasil penelitiannya. Sebagian besar guru menyatakan akan menyumbangkan artikelnya, tetapi realisasinya sangat rendah. Hanya beberapa guru yang telah menyumbangkan artikelnya. Guru yang menyumbangkan artikelnya ke JPP adalah guru-guru yang termasuk memiliki motivasi berprestasi tinggi. Pencermatan terhadap artikel yang masuk menunjukkan bahwa kemampuan guru-guru ini dalam menulis artikel masih kurang, apalagi guru-guru yang lain. Usaha keras dari penyunting dan penulis sebagai perpaduan dari tanggung jawab penyunting dan motivasi belajar dari penulis diperlukan untuk menjadikan artikel tersebut layak diterbitkan.

Dibalik kelangkaan calon penulis artikel di jurnal ilmiah, sesungguhnya di Bali calon penulis potensial sudah cukup banyak. Seiring dengan tuntutan menjadi guru profesional dan kesadaran akan meningkatkan kompetensi profesional melalui studi lanjut, beberapa guru sekolah menengah di Bali telah pernah melaksanakan penelitian tindakan kelas dan telah menyelesaikan studinya di program pasca sarjana. Demikian pula, beberapa di antara mereka sudah menyelesaikan studi di tingkat pascasarjana bidang pendidikan. Mereka ini adalah calon penulis artikel yang sangat memerlukan bantuan dalam melanjutkan produk ilmiahnya sampai pada muara akhir suatu karya ilmiah, yaitu publikasi. 
Hal yang sama terjadi di Kabupaten Klungkung dan Karangasem (daerah sasaran P2M ini). Beberapa guru di dua kabupaten ini telah aktif melakukan penelitian tindakan kelas dan menyelesaikan studinya di tingkat pascasarjana. Beberapa di antaranya ada yang berprestasi sampai tingkat nasional terkait dengan karya-karya inovatifnya, termasuk hasil penelitiannya. Namun, publikasi ilmiah khususnya di Jurnal Pendidikan dan Pengajaran dari dua kabupaten ini masih sangat kurang. Guru-guru ini adalah caloncalon penulis artikel potensial untuk ditingkatkan kemampuannya dalam menulis artikel ilmiah dari hasil penelitiannya, baik PTK maupun dari laporan tesisnya.

Menulis artikel ilmiah adalah sesuatu yang baru bagi kalangan guru. Hampir semua guru di Bali, termasuk Kabupaten Klungkung dan Karangasem mengalami permasalahan dalam menulis artikel ilmiah, baik artikel dari hasil penelitian, apalagi artikel tentang pemikiran ilmiah. Sebagai suatu keterampilan, menulis artikel tidak bisa dilakukan hanya melalui anjuran atau dorongan untuk menulis. Keterampilan menulis memerlukan pemahaman tentang hakikat artikel, tata tulis ilmiah, dan akan terbentuk melalui banyak latihan.

Berdasarkan permasalahan yang dipaparkan di atas, maka tujuan kegiatan ini adalah (1) meningkatkan kemampuan guru-guru SMP dan SMA di Kabupaten Klungkung dan Karangasem menulis artikel hasil penelitiannya sesuai dengan gaya selingkung jurnal nasional terakreditasi, dan (2) membantu guru-guru di Kabupaten Klungkung dan Karangasem mempublikasikan artikel hasil penelitiannya Jurnal ilmiah. Kegiatan ini diharapkan dapat membantu kelemahan guru dalam menulis artikel ilmiah dan membantu guru mempublikasikan naskah artikel hasil penelitiannya.

Jurnal Berkala ilmiah adalah wadah dokumentasi dan penyebarluasan hasil penelitian dan hasil pemikiran Ilmuwan. Melalui Jurnal berkala ilmiah, temuan penelitian diarsip sekaligus diakui kelayakan keilmuan yang dihasilkan oleh ilmuwan. Semua temuan penelitian direkam dan diorganisasi dalam jurnal-jurnal ilmiah untuk memperoleh pengakuan secara legal sebagai karya dari ilmuwan. Sebagai salah satu wadah/media publikasi, hasil-hasil penelitian maupu pemikiran baru dinyatakan terpublikasikan apabila dimuat dalam wadah publikasi seperti jurnal berkala ilmiah.

Berdasarkan lingkup artikel yang dimuat dan keluasan penyebarannya, jurnal berkala ilmiah dibedakan menjadi jurnal ilmiah lokal, jurnal ilmiah nasional, jurnal 
ilmiah internasional, dan jurnal luar negeri (Saukah, 2011). Berdasarkan status terakreditasi, jurnal dibedakan menjadi jurnal nasional tidak terakreditasi dan jurnal nasional terakreditasi. Semua jurnal yang artikelnya diakui angka kreditnya harus tercatat secara internasional sebagai nomor jurnal yang disebut dengan Internasional Standard Serial Number (ISSN).

Jurnal ilmiah lokal memiliki ciri-ciri: (1) artikelnya memuat karya ilmiah berupa artikel hasil penelitian dan hasil pemikiran; (2) penulisnya adalah dari kalangan unit kerja sendiri; (3) pengelola dan penyntingnya berasal dari unit kerja sendiri; dan (4) distribusi jurnalnya lebih banyak terbatas pada pada kalangan sendiri. Jurnal ilmiah nasional tidak terakreditasi memiliki ciri-ciri: (1) Keterlibatan pakar nasional berasal dari lingkungannya sebagai mitra bebestari; (2) penulisnya banyak dari luar lingkungan sendiri; (3)distribusi jurnal secara nasional; dan (4) tampilan dan dan kualitas isinya belum memenuhi kriteria akreditasi. Jurnal ilmiah nasional terakreditasi memiliki ciriciri: (1) Keterlibatan pakar nasional berasal dari lingkungannya sebagai mitra bebestari; (2) penulisnya banyak dari luar lingkungan sendiri; (3)distribusi jurnal secara nasional; dan (4) tampilan dan dan kualitas isinya telah memenuhi kriteria akreditasi.

Jurnal ilmiah luar negeri adalah jurnal yang diterbitkan di luar negeri. Jurnal ini bisa dikategorikan menjadi dua, yaitu Jurnal internasional dan jurnal bukan internasional. Jurnal ilmiah internasional memiliki ciri-ciri: (1) adanyany keterlibatan beberapa pakar yang bereputasi dalam bidangnya dari berbagai negara sebagai mitra bebestari; (2) penulis artikelnya berasal dari berbagai negara; (3) distribusi jurnal telah menjangkau berbagai negara; dan (4) menggunakan salah satu bahasa internasional.

Artikel ilmiah adalah penulisan secara ringkas dan padat bentuk esai dari temuan penelitian atau pemikiran ilmiah. Artikel ilmiah bukan ringkasan dari hasil penelitian, melainkan suatu formulasi penyampaian hasil penelitian yang memiliki ciri-ciri: (1) mempunyai bentuk, struktur, dan isi dengan sifat tertentu; (2) penulisannya mengikuti kaidah, pola dan teknik tertentu; dan (3) kaidah, pola dan teknik penulisannya dipengaruhi oleh gaya selingkung yang ditetapkan (Suhadi, 2011).

Sebagai artikel ilmiah, isinya harus menjunjung tinggi ciri-ciri ilmiah seperti objektif, rasional, kritis, dan pembaharu. Terkait dengan ciri-ciri ini, artikel ilmiah, sebagaimana karya ilmiah yang lain harus bebas dari duplikasi atau flagiasi. Aspek 
flagiasi ini menjadi penekanan penting dalam dunia publikasi. (Permendiknas No 17, 2010)

Ada beberapa bentuk artikel ilmiah sesuai dengan rekomendasi DP2M Kemendiknas (Suhadi, 2011), yaitu artikel hasil penelitian, artikel pemikiran ilmiah atau artikel konseptual, Review buku, dan obituari. Artikel Hasil penelitian memuat tentang uraian secara ringkas dan padat tentang penelitian. Tata tulis artikel hasil penelitian sedikit bervariasi tergantung pada jenis penelitian, apakah penelitian dasar, penelitian terapan, penelitian pengembangan, atau penelitian kualitatif. Artikel konseptual memuat hasil analisis dan pikiran kritis penulis. Artikel ini bukan sekedar tempelan (kolase) bagian dari tulisan-tulisan yang lain melainkan hasil analisis kritis penulis. Bagian paling vital dari artikel konseptual adalah pendapat atau pendirian penulis.

Selain harus memenuhi kaidah bahasa, tata tulis artikel juga memiliki bentuk, struktur, dan isi yang tertentu. Menurut Peraturan DIKTI No 49 Tahun 2011 tentang Pedoman Akreditasi Jurnal Berkala Ilmiah, tata tulis artikel dan kualitas isi merupakan aspek yang sangat besar bobotnya dalam penilaian kualitas jurnal, dan juga penilaian dari artikel itu sendiri. Setiap jurnal memiliki tata penulisan artikel yang sedikit berbeda dari sisi bentuk dan struktur, namun memiliki standar substansi yang sama. Jurnal yang sudah terakreditasi atau sedang didorong untuk mencapai akreditasi memiliki standar substansi yang sama mengacu pada pedoman akreditasi dari DIKTI.

Jurnal Pendidikan dan Pengajaran (JPP) yang dinaungi oleh Undiksha adalah salah satu jurnal nasional yang didorong untuk meraih status akreditasi. Oleh sebab itu tata tulis (gaya selingkung) JPP Undiksha sudah disesuaikan dengan standar penulisan artikel di jurnal nasional terakreditasi. Standar mutu/kualitas artikel dari jurnal berkala ilmiah nasional sesuai dengan Pedoman Akreditasi Peraturan Dikti 492011 dapat disarikan ke dalam rumusan praktis dari substansi pokok artikel ilmiah, yaitu Judul, Abstrak (bahasa Inggris dan Indonesia), Pendahuluan, Metode (artikel hasil penelitian), Hasil dan Pembahasan (hanya Pembahasan untuk artikel hasil pemikiran), Simpulan, dan Daftar Rujukan. Secara lebih rinci acuan praktis standar mutu artikel ilmiah hasil penelitian dan hasil pemikiran adalah sebagai berikut.

(1) Judul diharapkan bernuansa nasional atau global, maksimum 12 kata (lokasi penelitian tidak disebut di judul, tetapi ada di metode). 
(2) Abstrak bahasa Inggris dan Bahasa Indonesia memuat tiga hal pokok (a) tujuan, (b) ringkasan metode, dan (3) hasil/temuan penelitian.

(3) Pendahuluan memuat (a) paparan perkembangan terkini bidang ilmu yang diteliti yang argumentasinya didukung oleh hasil kajian pustaka primer dan mutakhir untuk memdukung masalah, (b) paparan kesenjangan, (c) argumentasi peneliti dalam menutup kesenjangan tersebut sebagai janji kontribusi penelitian ini bagi perkembangan ilmu, dan (d) paparan tujuan penelitian

(4) Metode memuat paparan tentang segala sesuatu yang memang dilakukan oleh peneliti dalam melakukan penelitian secara jelas seolah-olah memberi peluang peneliti lain untuk melakukan replikasi atau verifikasi terhadap penelitiannya. Hindari definisi-definisi yang dikutip dari buku dalam paparan di bagian Metode. Desain penelitian yang sudah menjadi pengetahuan umum tidak perlu ada sumber yang dirujuk.

(5) Hasil dan Pembahasan dipaparkan secara berurutan atau terpadu dalam bagian "Hasil dan Pembahasan" tergantung pada jenis penelitian.

a. Paparan bagian hasil berisi hasil analisis data, sebaiknya berupa tabel/bagan/gambar berisi paparan hasil analisis yang sudah bermakna dan mudah dipahami maknanya secara cepat. Tabel/bagan/gambar tidak berisi data mentah yang masih dapat diolah.

b. Paparan bagian pembahasan berisi pemberian makna secara substansial terhadap hasil analisis dan perbandingan dengan temuan-temuan sebelumnya berdasarkan hasil kajian pustaka yang relevan, mutakhir dan primer. Perbandingan tersebut sebaiknya mengarah pada adanya perbedaan dengan temuan penelitian sebelumnya sehingga berpotensi untuk menyatakan adanya kontribusi bagi perkembangan ilmu (delta).

(6) Simpulan (maksimal 1 halaman)

a. dalam bentuk alinea (bukan numerik)

b. berisi temuan penelitian sebagai sintesis antara hasil analisis data dan hasil pembahasan,

c. lebih menonjolkan hal-hal yang baru yang memberikan kontribusi bagi perkembangan ilmu (delta). 
d. Hindari penggunaan istilah teknis statistik dan metodologi penelitian.

(7) Daftar rujukan berisi semua yang dirujuk dalam teks yang berasal dari sumber yang (a) relevan, (b) minimal 80\% mutakhir (10 tahun terakhir), dan (c) minimal 80\% primer, terutama dari artikel jurnal.

Artikel harus dilengkapi dengan abstrak berbahasa Inggris yang merupakan terjemahan dari abstrak dalam bahasa Indonesia. Kata kunci tidak perlu diterjemahkan ke dalam bahasa Inggris, cukup dalam bahasa Indonesia dan dicantumkan setelah abstrak dalam bahasa Inggris. Abstrak artikel hasil penelitian setidaknya memuat tiga hal pokok, yaitu: (a) tujuan penelitian, (b) metode penelitian, dan (c) hasil penelitian. Abstrak diketik menggunakan spasi tunggal. Abstrak dilengkapi dengan kata kunci (3 sampai 5 kata kunci) yang berfungsi untuk memudahkan pencarian artikel ini secara elektronik.

Pendahuluan memuat tiga hal pokok, yaitu: latar belakang, rangkuman teoritik, dan tujuan penelitian. Tinjauan pustaka diintegrasikan dalam paparan pendahuluan. Semua referensi yang dirujuk dalam paparan, (Nama, tahun) untuk kutipan tidak langsung atau (Nama, tahun: hlm) untuk kutipan langsung, dicantumkan di dalam Daftar Rujukan. Pendahuluan diharapkan maksimum 30 persen dari keseluruhan artikel. Alenia berikutnya dari paparan pendahuluan dibuat menjorok ke dalam sesuai dengan penulisan alenia baru pada umumnya.

Metode penelitian disesuaikan dengan jenis penelitian. Penelitian kualitatif memiliki langkah metodologi yang berbeda dengan penelitian kuatitatif, seperti eksperimen. Walaupun demikian, pada bagian METODE diharapkan cukup jelas paparan tentang: rancangan penelitian, subjek/populasi-sampel/fokus dan objek penelitian, teknik pengumpulan data dan isntrumen penelitian, dan teknik analisis data.

Bagian hasil penelitian dibuat dalam satu subjudul yang terpisah dengan bagian pembahasan. Untuk penelitian kualitatif, bagian hasil dan pembahasan dapat dibuat secara terintegrasi.

Data yang disajikan dalam hasil penelitian bukan berupa data 'mentah', melainkan data yang sudah diolah. Hasil disajikan dalam bentuk tabel, grafik, atau bagan yang dilengkapi dengan penjelasan. Penjelasan tabel/grafik/bagan tidak menyebutkan ulang 
isi tabel, melainkan mendeskripsikan/memformulasikan maknanya. Tabel, grafik, atau bagan masing-masing diberikan nomor dan judul.

Paparan pada pembahasan memuat hal-hal pokok berikut, yaitu: (a) menjawab pertanyaan-pertanyaan penelitian, (b) memaparkan logika diperolehnya temuan, (c) menginterpretasi temuan, dan (d) mengaitkan temuan dengan teori atau kajian empiris lain yang relevan. Semua referensi yang dirujuk dalam paparan, (Nama, tahun) untuk kutipan tidak langsung atau (Nama, tahun: hlm) untuk kutipan langsung, dicantumkan di dalam Daftar Rujukan.

Simpulan dibuat dalam paragraf pendek yang memuat tentang esensi dari hasil penelitian yang tertuang dalam tujuan penelitian. Simpulan harus relevan dengan temuan dan hindari generalisasi yang berlebihan.

Semua rujukan yang dimuat dalam paparan artikel harus dicantumkan pada daftar rujukan, atau sebaliknya. Sumber yang dirujuk sedapat mungkin (minimal 80\%) merupakan pustaka-pustaka terbitan 10 tahun terakhir. Rujukan yang diutamakan adalah sumber-sumber primer berupa laporan penelitian (termasuk skripsi, tesis, disertasi) atau artikel-artikel penelitian dalam jurnal atau majalah ilmiah. Daftar rujukan disusun dengan tata cara seperti sudah diuraikan di atas.

Untuk Artikel Konseptual, pedoman penulisannya di JPP sedikit mengalami modifikasi dari artikel hasil penelitian. Abstrak berupa komentar atau pengantar dari penulis. Abstrak memuat: (a) tujuan penelitian, (b) isu-isu pokok, dan (c) alternatif pemecahan. Pendahuluan memuat hal pokok, yaitu: latar belakang atau acuan permasalahan, hal-hal menarik yang belum tuntas, perkembangan baru, dan tujuan penelitian. Semua referensi yang dirujuk dalam paparan, (Nama, tahun) untuk kutipan tidak langsung atau (Nama, tahun: hlm) untuk kutipan langsung, dicantumkan di dalam Daftar Rujukan. Pendahuluan diharapkan maksimum 20 persen dari keseluruhan artikel. Paparan pada pembahasan dapat dibagi menjadi beberapa subjudul. Pembahasan berupa kupasan yang sifatnya analitik, argumentatif, logis, dan kritis. Isi pembahasan adalah cermin dari pendirian/sikap penulis terhadap permasalahan yang menjadi fokus tulisan. Semua referensi yang dirujuk dalam paparan, (Nama, tahun) untuk kutipan tidak langsung atau (Nama, tahun: hlm) untuk kutipan langsung, dicantumkan di dalam Daftar Rujukan. Simpulan dibuat dalam paragraf pendek yang memuat tentang 
penegasan pendirian penulis dan saran-saran. Simpulan ditulis maksimum $10 \%$ dari keseluruhan isi artikel.

\section{Metode Pelaksanaan Kegiatan}

Khalayak sasaran strategis dari kegiatan P2M ini adalah guru-guru di Kabupaten Klungkung dan Karangasem yang telah memiliki penelitian yang belum dipublikasikan. Kegiatan pelatihan dan pendampingan penulisan karya ilmiah hasil penelitian terhadap khalayak sasaran di atas dilakukan dengan langkah-langkah sebagai berikut. Penulis berkoordinasi dengan pengurus MGMP berbagai bidang studi di kabupaten Klungkung dan Karangasem tentang kegiatan P2M yang dilaksanakan, seperti: Jenis kegiatan, sasaran kegiatan, waktu pelaksanaan. Koordinasi ini dilakukan untuk memperoleh informasi tentang guru-guru yang aktif meneliti dalam bidang pendidikan dan pembelajaran dan belum mempublikasikan hasil penelitiannya. Guru-guru ini selanjutnya menjadi khalayak sasaran dari kegiatan P2M ini. Melalui MGMP masingmasing, beberapa anggota yang aktif meneliti ditunjuk sebagai peserta. Pada kegiatan koordinasi ini juga dijajagi tempat kegiatan pelatihan dan pendampingan. Pengurus dari salah satu MGMP bidang studi diharapkan dapat membantu pelaksana menyiapkan prasarana dan sarana penunjang pelaksanaan kegiatan pelatihan.

Kegiatan awal yang dilakukan adalah seminar lokakarya untuk memberikan wawasan secara komprehensif tentang artikel hasil penelitian dan penulisan artikel sesuai gaya selingkung JPP (salah satu jurnal nasional). Kegiatan ini merupakan kelanjutan dari seminar lokakarya yang bertujuan untuk lebih memperdalam pemahaman peserta tentang penulisan artikel sesuai dengan gaya selingkung JPP sekaligus membedah tata tulis sesuai dengan kaidah bahasa tulis artikel. Bedah artikel ini diharapkan menjadi sarana belajar peserta untuk meningkatkan pemahaman tentang tata tulis dan juga substansi artikel yang diharapkan.

Dari dua kegiatan sebelumnya, peserta dipandang sudah memiliki pemahaman yang memadai tentang penulisan artikel hasil penelitian yang berkualitas. Kegiatan pendampingan dilakukan untuk membantu peserta menyelesaikan artikel hasil penelitiannya sampai siap diproses dan layak diterbitkan di Jurnal Pendidikan dan pengajaran Undiksha (JPP), salah satu jurnal yang sedang mengebangkan statusnya menjadi jurnal nasional terakreditasi. Teknis pendampingan dilakukan secara online. 
Evaluasi kegiatan P2M ini dilihat dari dua aspek, yaitu (1) keterlibatan peserta dan (2) output kegiatan. Indikator keberhasilan kegiatan dilihat dari dua komponen evaluasi tersebut. Kegiatan P2M ini mentargetkan keterlibatan peserta minimal 10 orang guru yang berpartisipasi aktif dalam mengikuti seluruh rangkaian kegiatan. Output yang ditargetkan adalah dihasilkannya minimal 4 artikel yang memenuhi gaya selingkung JPP dan siap diproses untuk diterbitkan di JPP

\section{Hasil dan Pembahasan}

Kegiatan pokok yang dilakukan dimulai dari (1) persiapan materi seminar dan pelatihan; (2) Koordinasi tentang peserta seminar dan pelatihan serta waktu dan tampat pelaksanaan kegiatan; dan (3) kegiatan pelatihan. Persiapan materi seminar dilakukan di Bulan Mei dan Juni 2013. Pada persiapan materi dibuat makalah tentang penulisan artikel hasil penelitian sesuai dengan gaya selingkung JPP Undiksha yang dilengkapi dengan instrumen untuk membedah artikel, pembuatan Power Point, dan pemilihan artikel yang baik untuk dibedah peserta. Kegiatan koordinasi dengan calon peserta dan penetepan peserta, waktu dan tempat dilakukan pada bulan Juli dan Agustus 2013.

Kegiatan Seminar dan pelatihan serta bedah artikel dilakukan pada Tanggal 30 Agustus 2013 yang dilaksanakan di SMAN 2 Semarapura. Jumlah peserta seminar dan pelatihan adalah 20 orang. Susunan acara dan daftar peserta terlampir pada Lampiran 1. Kegiatan pendampingan terhadap naskah artikel yang sudah cukup memadai diproses di JPP dilakukan setelah seminar dan pelatihan secara online. Walaupun sudah diberikan penekanan pada saat koordinasi, tidak semua peserta membawa naskah artikel yang lengkap. Ada 6 peserta yang hanya membawa abstrak dan naskah artikel yang belum selesai dibuat dan 2 peserta malahan ada yang membawa ide penelitiannya untuk didiskusikan. Secara umum peserta antusias mengikuti seminar tentang cara penulisan artikel hasil penelitian di JPP Undiksha. Materi tentang penulisan artikel ilmiah yang diberikan mengacu pada standar kualitas artikel ilmiah menurut Peraturan Dikti n0 49 tahun 2011. Pada kegiatan seminar juga disampaikan wawasan jurnal ilmiah lokal, nasional, nasional terakreditasi, internasil dan jurnal luar negeri (Saukah, 2011). Kegiatan seminar ini dilanjutkan dengan bedah artikel dengan instrumen yang sudah disiapkan. Para peserta mendiskusikan /mengevaluasi substansi naskah artikel yang diberikan mengacu pada instrumen yang diberikan. 
Pada kegiatan pelatihan, tidak semua peserta fokus untuk menyempurnakan naskah artikel. Peserta yang naskahnya belum selesai dibuat ditempat pelatihan. Karena keterbatasan waktu, naskah-naska artikel peserta ini belum selesai dikerjakan selama pelatihan. Peserta yang tidak membawa naskah artikel hanya mendampingi temannya bekerja menyempurnakan naskah artikelnya. Peserta yang belum selesai naskah artikelnya, termasuk yang sudah selesai (lengkap komponen pokok artikel) diharapkan untuk melanjutkan penyempurnaannya di rumah masing-masing, selanjutnya diemail ke tim pelaksana. Beberapa foto kegiatan Seminar, bedah artikel, dan pelatihan.

Pada akhir dari kegiatan seminar dan pelatihan, terkumpul 14 naskah artikel sebagai produk pelatihan. Secara umum produk pelatihan belum sesuai dengan harapan karena keterbatasan waktu dalam pendampingan saat tatap muka. Di samping itu, untuk menghasilkan suatu artikel dengan kualitas baik diperlukan waktu yang cukup walaupun peserta sudah memahami tentang tata tulis dan substansi artikel yang baik. Dari 14 naskah artikel yang dihasilkan, ada empat naskah yang kualitasnya memadai yang siap diproses (didampingi) lebih lanjut di JPP Undiksha.

Kegiatan pelatihan dan pendampingan penulisan artikel ilmiah bagi guru-guru sekolah menengah sangat relevan dengan kebutuhan guru seiring dengan tuntutan guru profesional. Guru sekarang ini dituntut untuk mampu menulis karya ilmiah sekaligus mempublikasikannya, sementara kemampuan guru dalam menulis, khususnya artikel ilmiah masih kurang. Secara umum, animo guru untuk mengikuti kegiatan ini tinggi. Namun karena keterbatasan dana, Sebagian dari guru yang berminat sebagai peserta tidak bisa dilibatkan.

Walaupun peserta dikenai persyaratan sudah memiliki draft artikel hasil penelitian. Tetapi sebagian guru ternyata belum siap dengan draf artikelnya. Guru-guru yang sudah menyelesaikan studi lanjut S2 sudah memiliki draf artikel. Sementara guru yang belum studi atau yang sedang studi naskahnya masih sangat kurang lengkap. Walaupun belum mempunyai draft naskah, beberapa guru ini memiliki motivasi yang tinggi untuk menambah kemampuannya dalam menulis artikel sehingga mereka tetap ingin menjadi peserta.

Dari naskah yang masuk terlihat bahwa kemampuan menulis artikel ilmiah peserta relatif masih kurang. Walaupun peserta sudah menyelesaikan studi di S2, kemampuan 
mereka dalam menulis artikel masih termasuk kurang. Guru-guru sepertinya belum pernah mendapat pelatihan atau bimbingan secara inten terkait dengan menulis artikel sehingga kemampuan mereka relatif sama. Banyak peserta belum memahami sistematika penulisan artikel ilmiah hasil penelitian, lebih-lebih, substansi dari masingmasing bagian dari artikel. Draf artikel yang dibuat peserta masih cenderung berbentuk ringkasan hasil penelitian. Padahal, artikel ilmiah bukan ringkasan dari hasil penelitian, melainkan suatu formulasi penyampaian hasil penelitian yang memiliki ciri-ciri: (1) mempunyai bentuk, struktur, dan isi dengan sifat tertentu; (2) penulisannya mengikuti kaidah, pola dan teknik tertentu; dan (3) kaidah, pola dan teknik penulisannya dipengaruhi oleh gaya selingkung yang ditetapkan (Suhadi, 2011).

Pada kegiatan seminar, peserta diberikan informasi secara rinci tentang sistematika dan isi dari masing-masing bagian artikel. Informasi tentang apa yang ditulis pada setiap bagian artikel sangat membantu guru memahami cara menulis artikel yang baik. Guru juga diberikan wawasan bahwa menulis artikel tidak lepas dari kemampuan dalam bahasa tulis. Oleh sebab itu, penulis artikel ilmiah juga harus meningkatkan kemampuan dalam bahasa tulis. Secara umum, pengetahuan peserta tentang artikel dan cara menulis artikel ilmiah meningkat. Di samping itu, wawasan peserta tentang jurnal dan artikel juga meningkat. Meningkatnya pengetahuan peserta dalam menulis artikel yang baik tidak serta merta tercermin dari produk kegiaatan seminar dan pelatihan. Terbatasnya waktu pendampingan tatap muka menyebabkan peserta belum rampung dalam menyempurnakan naskahnya sesuai dengan pengetahuan yang diperoleh. Walaupun demikian, beberapa artikel peserta seminar dan pelatihan cukup bagus. Ada empat naskah artikel produk seminar dan pelatihan yang tergolong memadai untuk diproses lebih lanjut di JPP Undiksha. Naskah ini masih perlu diproses melalui pendampingan secara online oleh tim pelaksana yang kebetulan adalah tim penyunting pelaksana di JPP Undiksha.

Sesuai dengan indikator pencapaian kegiatan (evaluasi kegiatan), hasil yang dicapai dari kegiatan pengabdian masyarakat ini termasuk kategori baik. Indikator keberhasilan dari sisi jumlah pesertaa sudah terlampui, yaitu lebih dari 10 orang. Demikian pula, produk artikel dengan kualitas memadai untuk diproses lebih lanjut di JPP sebanyak 
empat. Indikator pencapaian kegiatan dari aspek produk ini adalah 4 naskah artikel dengan kualitas memadai.

\section{Penutup}

Kegiatan pengabdian masyarakat ini dapat meningkatkan pengetahuan dan kemampuan guru peserta dalam menulis artikel hasil penelitian sesuai dengan gaya selingkung JPP, jurnal yang menuntut standar kualitas artikel sesuai dengan Peraturan DIKTI No 49 Tahun 2011. Ada empat artikel hasil produk pelatihan yang akan terus didampingi untuk diproses dan berpotensi dipublikasi di JPP Undiksha . Dengan demikian, kegiatan ini secara real dapat membantu guru peserta untuk mempublikasi artikel hasil penelitiannya.

Kemampuan dalam menulis artikel di kalangan guru masih perlu ditingkatkan. Tuntutan propfesionalisme guru telah menciptakan kebutuhan bagi guru untuk meningkatkan kemampuan menulis artikel ilmiah. Oleh sebab itu kegiatan pengabdian seperti yang dilakukan ini akan terus relevan dan dibutuhkan oleh guru-guru. Di sisi lain, rendahnya publikasi ilmiah di Indonesia disebabkan oleh rendahnya kualitas naskah yang disumbangkan oleh penulis. Dengan demikian, kegiatan pengabdian masyarakat terkait dengan penulisan artikel ilmiah ini perlu diperhatikan dan dipertimbangkan oleh LPM untuk didanai.

\section{DAFTAR PUSTAKA}

Pedoman Penulisan Artikel Ilmiah . 2012. Jurnal Pendidikan dan Pengajaran (JPP).

(Online), (http://www.undiksha.ac.id/jpp, diakses 20 Agustus 2012).

Peraturan Diknas No 17. 2010. Pencegahan dan Penanggulangan Plagiat di Perguruan

Tinggi. Jakarta: Mendiknas.

Peraturan Dikti No 11. 2011. Pedoman Akreditasi Jurnal Berkala Ilmiah Nasional. Jakarta: Dikti.

Peraturan Menpan No. 16. 2009. Fungsional Guru dan Angka Kreditnya. Jakarta: Menpan.

Saukah, A. 2011. Kebijakan Pengembangan Berkala Ilmiah dan Pelajaran Terpetik dari Kegagalan Terakreditasi. Materi Pelatihan Nasional Penulisan Artikel Ilmiah. Malang: JIP Malang. 
Saukah, A. \& Waseso, M. G. 2006. Menulis Artikel untuk Jurnal Ilmiah. Malang: Universitas Negeri Malang.

Suhadi, Ibnu. 2011. Isi dan Format Jurnal Ilmiah. Materi Pelatihan Nasional Penulisan Artikel Ilmiah. Malang: JIP Malang. 